\title{
$\mathrm{CMG}$ ユニットを用いたロープ型宇宙 エレベーター実験用クライマーの昇降安定化制御
}

\author{
江上 正* 長 島 祥* 梅 本 和 希*
}

\section{Lift Stabilization Control for an Experimental Space Elevator Climber for a Rope-type Tether using a CMG Unit}

\author{
Tadashi Egami*, Akira Nagashima* and Kazuki Umemoto*
}

\begin{abstract}
By using a tether (cable) to link the ground station and the space station at $36,000[\mathrm{~km}]$ altitude, a space elevator is envisioned where transportation is achieved by a climber that ascends and descends the tether. In anticipation of industrial applicability near the ground, a climber for a rope-type tether (rope-type climber) was developed in this study. Compared with a climber for a belt-type tether, the rope-type climber has a small contact area between the tether and the roller, leading to problems with slippage and roller deterioration. Accordingly, here the contact area between the rope and roller was increased by using four drive wheels, and synchronized velocity control was accomplished with two drive motors for two drive wheels. Also the rope-type climber has more difficulty maintaining its orientation and is easily rotated around the tether by wind and other factors, so a control moment gyro (CMG) unit was developed that can be applied to the climber. An optimal servo system using a disturbance observer was applied to a rope-type climber with the developed CMG unit to achieve lift stabilization control. Then the effectiveness of the developed system was verified in lift experiments at the $25[\mathrm{~m}]$ outdoor test site of Kanagawa University and in a $1.2[\mathrm{~km}]$ lift experiment at the Space Elevator Challenge.
\end{abstract}

Key Words: Space Elevator, Climber for Rope-type Tether, Control Moment Gyro, Disturbance Observer, Optimal Servo System

1.は じめに

3 万 $6,000[\mathrm{~km}]$ 上空の静止ステーションと地上をテザー（ケー ブル)によりつないで，そのテザーをクライマー(昇降機)が昇 降するという輸送機関である宇宙エレベーターが構想されてい る. 宇宙エレベーターの概念は, 1959 年にユーリ・アルッター ノフによって発表されていたが，十分な強度をもったケーブル の素材が存在しなかったために概念だけのものであった。しか し，1991 年の極めて高い機械的強度をもつカーボンナノチュー ブの発見以来，実現の可能性は高まってきている．テザーに関 しては宇宙空間ではスペースデブリなどとの衝突により損傷し ても，損傷箇所を補修しやすいべルト型テザーが有利とされて いるが, 大気圈内では風などの環境の影響からロープ型テザー が有利とされており, 最近では宇宙空間ではべルト型, 大気圈 内ではロープ型といったように使用高度に合わせて最適な形状 を使用するハイブリット型テザーも構想されている．このため

原稿受付 2016 年 1 月 14 日

*神奈川大学大学院工学研究科

* Graduate School of Engineering, Kanagawa University

口本論文は提案性（システム設計・構築分野）で評価されました。
筆者らは，ベルト型，ロープ型テザー双方に対応した実験用ク ライマーの研究開発を行っている.

宇宙エレベーター開発の現状に関しては, 2002 年に NASA の研究機関が Bradley Edward 博士の実現案についてのレポー 卜を発表し [1]，NASAの支援を受けたSpaceward 財団が 2005 年から 2009 年まで, 主にエネルギー供給を主眼としたクライ マーの競技会を開催して $1[\mathrm{~km}]$ の昇降に成功している. 日本で も2008 年より宇宙エレベーター協会が活動を開始し，2009 年 度よりクライマーの機構を主眼とした宇宙エレベーター技術競 技会（第 5 回大会からは宇宙エレベーターチャレンジ）を開催 し， 2014 年度の第 6 回大会では $1.2[\mathrm{~km}]$ の昇降に成功するク ライマーも現れている. 2012 年には大林組による宇宙エレベー ターの建設に焦点を当てた建設構想も発表されている [2].

このような中で筆者らは, 第 1 回大会から参加するとともに 運営にもかかわってきている，ただし，現状では宇宙空間まで 移動可能な宇宙エレベーターそのものを扱うのは実際上困難で あるので，地上から $10[\mathrm{~km}]$ 程度の成層圈くらいまでを想定し て，宇宙エレベータークライマーとして必要と想定される機能 についての試作と制御に関して検討を行っている．現在までに 車輪の最適配置，屋内試験装置，押付力調整機構，ジャイロを 
用いた姿勢制御などに関する試作と制御を行ってきている.

このような中で本論文では，地上付近での産業応用も見据え てロープ型テザーに対応したロープ型クライマーを開発した。 ロープ型テザーは前述したように宇宙エレベーターの大気圈で のテザーとして考えられているほか, 地上付近の産業応用には ベルト型テザーよりも風の影響を受けにくく扱いやすい点で有 利である。，一方，クライマー開発に当たってはこのロープ型ク ライマーはベルト型クライマーに比ベて，ローラのテザーとの 接触面積が小さいため, 滑りやすく, ローラも摩耗しやすいと いう問題点がある. またロープ型クライマーはベルト型に比べ て，風，ロープ径の変化，ロープのねじれなどの影響によりロー プテザー周りに姿勢を保つことが難しく，回転しやすいという 問題点もある.

このため本論文では，駆動輪を四つにしてローラとロープの 接触面積を増やした。駆動輪を四つにした場合，それぞれの駆 動輪に異なった負荷が掛かり，回転速度が異なると駆動輪が滑っ て摩耗が大きくなってしまうため，それぞれの駆動輪を同期さ せる必要がある。しかしすべてを機械的に結合して同期させる と各車輪への負荷が大きく異なる場合，結合部に大きな負荷が 掛かって，ゆがみや破損の原因となってしまう。そこで本研究 では，それぞれ二つの駆動輪を駆動する 2 個の駆動モー夕に対 して最適同期化速度制御を行った。

ロープテザー周りの姿勢制御に関しては，人工衛星などでは 姿勢制御にコントロール・モーメント・ジャイロ $(\mathrm{CMG})$ が用 いられているため，本論文ではクライマーに適用可能な CMG ユニットを開発して検討を行った.

このロープ型クライマーや CMG ユニットに対して，外乱才 ブザーバ [3] [4] を用いて等価外乱を除去したノミナルモデルを 与え，最適制御系を適用して昇降安定化制御を行うことでモー 夕に外乱が加わった場合や仕様が不明確なモー夕を使用する場 合でもロバストに走行できるようにした，この結果，本研究で 開発したロープ型クライマーは 2014 年の第 6 回宇宙エレベー ターチャレンジにおいて $1,150[\mathrm{~m}]$ の昇降距離を達成し, これ はロープ型クライマーの世界最高高度記録となっている。

本論文では，開発した $\mathrm{CMG}$ ユニットを用いたロープ型クラ イマーや用いた制御系について論じ，神奈川大学に設置された $25[\mathrm{~m}]$ の屋外試験場での昇降実験や宇宙エレベーターチャレン ジでの $1[\mathrm{~km}]$ 越え昇降実験などによりその有効性を確認する.

\section{2. クライマーの製作}

実験用のロープ型クライマーを製作するにあたり，「4 輪駆 動」,「メンテナンスの簡易化」，「機体フレーム部分の安全率の 確立」，「CMG ユニット搭載」を基本コンセプトとして設計 • 製作を行った。 また，設計条件として，宇宙エレベーターチャ レンジでの規定などを考慮して想定重量 15 [kg] 以内, 最高速度 $5[\mathrm{~m} / \mathrm{s}]$ と定めた．本クライマーは大きく分類すると，駆動部， テザーガイド, モータドライバ・バッテリボックス，マイコン ボックスから構成されている.

\section{1 クライマー本体の製作}

本研究では本体をいくつかに分解できるようにすることでメ ンテナンスを容易とし, 部品単体に掛かる重量を想定機体重量
である $15[\mathrm{~kg}]$ として SolidWorks を用いて強度計算を行い，す べての部品の安全率を 1.5 以上にするように設計を行った。ま た CMG ユニットは着脱可能な機構とした. Fig. 1 (a), (b) に

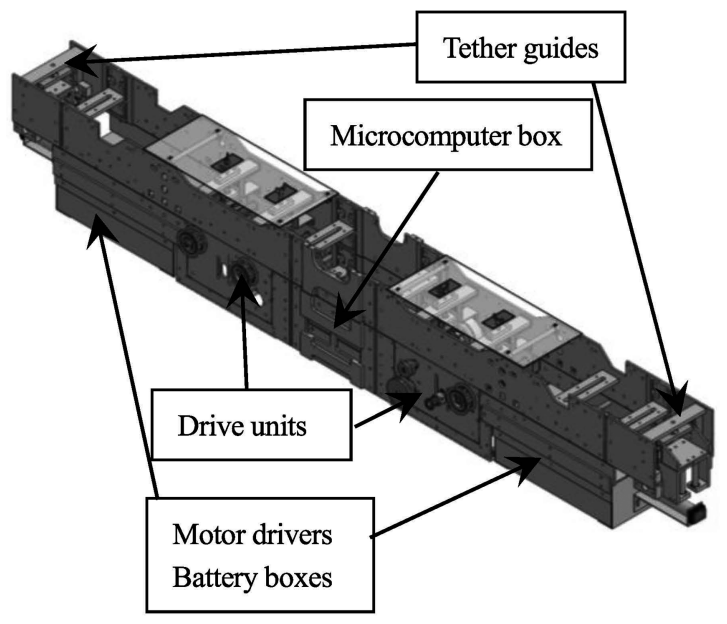

(a) General view

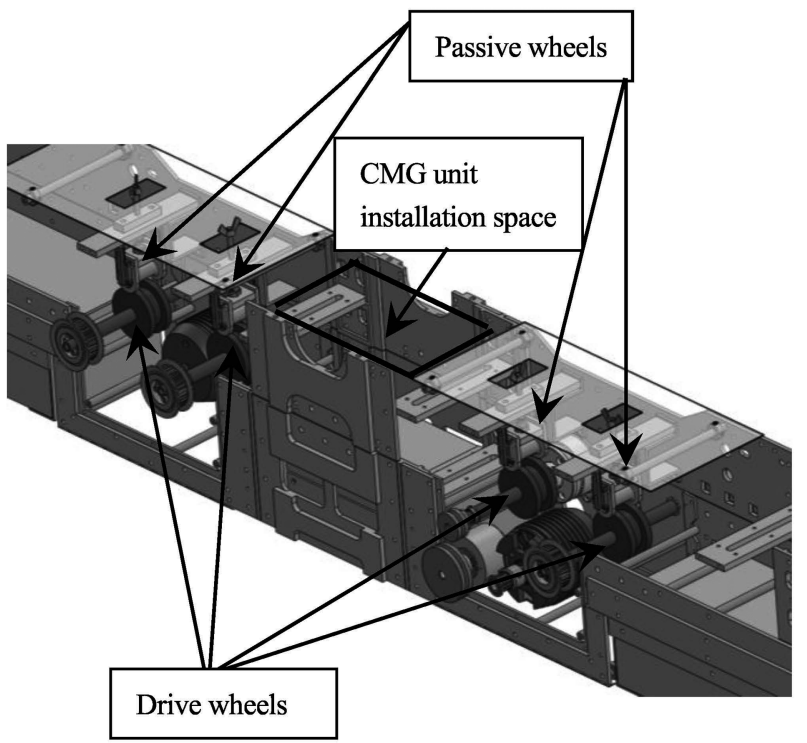

(b) Elements on large scale

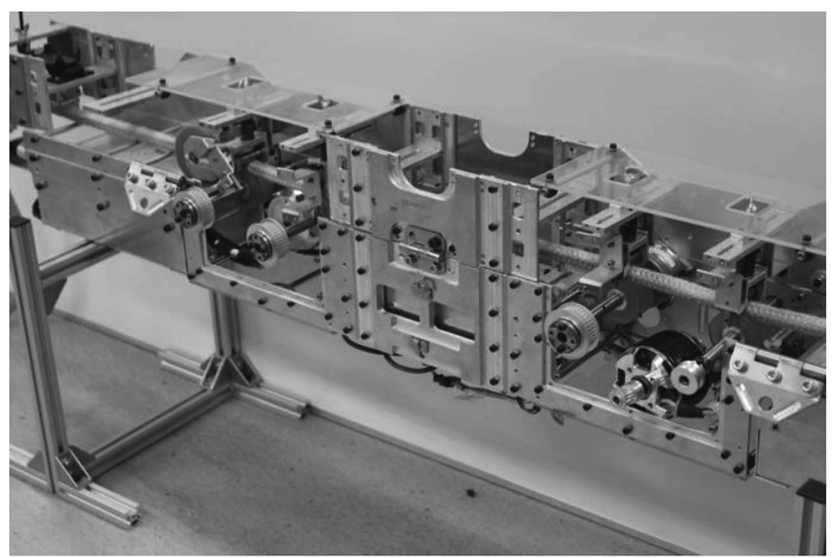

(c) Photo

Fig. 1 Manufactured experimental climber 
設計したロープ型クライマーの外観図を示し，(c)に製作した 写真（ロープを通し，外装の一部を取り外したもの）を示す。

実際に製作したクライマーの重量は約 $12.1[\mathrm{~kg}]$, 全長は約 $1,250[\mathrm{~mm}]$, 幅約 $110[\mathrm{~mm}]$, 高さ約 $180[\mathrm{~mm}]$ となっている. 機体は大きく分けて二つのパーツに分かれている. 片方には駆 動輪やモータ, マイコン, バッテリなどが搭載されており，も う片方には受動輪や CMG ユニットなどが搭載される.テザー がロープ型の場合，摩擦を得にくいため，4 輪駆動にすること でロープとの接触面積を増やしている.

モータは最大出力 $4,200[\mathrm{~W}]$ のブラシレスモータを 2 個使用 し, 逆回転が可能なドライバを 2 個使用している. 駆動輪は直径 $40[\mathrm{~mm}]$ のウレタンゴムに溝加工を施し, 受動輪は直径 $10[\mathrm{~mm}]$ のクロム軸受鋼鋼材を用いている. 一つのモータで二つの駆動 輪を機械的に結合し, 二つのモータは最適同期化速度制御を行っ ている. ブレーキは無励磁作動電磁ブレーキを使用している. セ ンサは駆動輪と受動輪のそれぞれにロータリーエンコーダを用 いており, 受動輪と駆動輪の速度を検出することにより車輪速 度と機体速度が検出でき, 機体のすべりを検出することができ る.また機体の前後にはテザーガイドを設置している.

\section{$2.2 \mathrm{CMG}$ ユニットの製作}

ジャイロには外部から自転軸を回すようにモーメントが加え られるとき, 加えられているモーメントの軸および自転軸と直 交する軸について振れ回り運動をする性質があるため, この性 質を利用し姿勢を制御する。このため，クライマーへの簡易的 な取り付けも基本コンセプトにした $\mathrm{CMG}$ ユニットの設計・製 作を行った。

今回製作した CMG ユニットはバッテリやマイコンなどをユ ニット側に搭載し, クライマーに搭載する際は 4 本のボルトで 締結するだけなので簡易的な搭載を可能にしている. Fig. $2(\mathrm{a})$ に製作した CMG ユニットの外観図を示し，(b)にその実際の 写真を示す．本ユニットは大きく分類すると, フライホイール 動作部，モータドライバ・バッテリボックス，マイコンボック スから構成されている. 重量は約 $4.1[\mathrm{~kg}]$, 全長は約 $200[\mathrm{~mm}]$, 幅 $500[\mathrm{~mm}]$, 高さ $225[\mathrm{~mm}]$ となっており, 二つあるフライホ イールにそれぞれ 1 個ずつ回転用モータとサーボモータを使用 している．また，昇降方向と垂直になるようにフライホイール の回転軸を設置している. 姿勢制御に必要なジンバルの角度変 化はサーボモータの PWM 制御で角度制御を行っており, 有効 角度は $\pm 45^{\circ}$ とした。

製作した CMG ユニットを搭載したクライマーの写真を Fig. 3 に示す.

\section{3. 制御系の設計}

本研究では本体と CMG ユニットの制御系を別々に構成した. 本体に用いたモータは, 高速回転可能なラジコンヘリコプタ用 のモータである. 特性があまり明確ではないため, 本論文では外 乱オブザーバ [3] [4] を用いて, 本体は最適同期化速度制御系 [5], $\mathrm{CMG}$ ユニットは最適サーボ系 [6] を構成する.

\section{1 クライマー本体の同期化速度制御}

用いたモータの運動方程式を

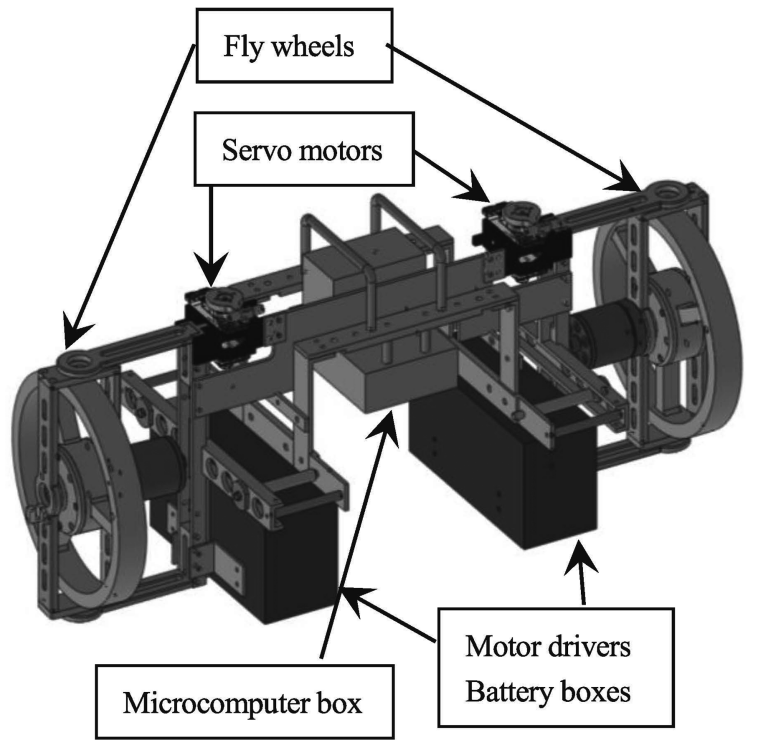

(a) General view

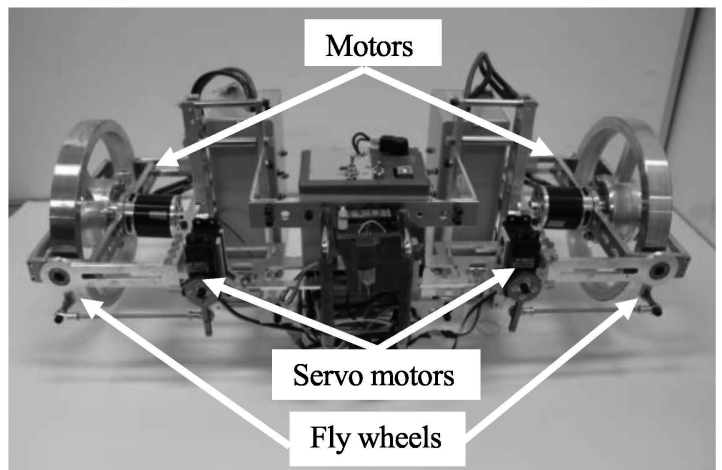

(b) Photo

Fig. 2 Manufactured CMG unit

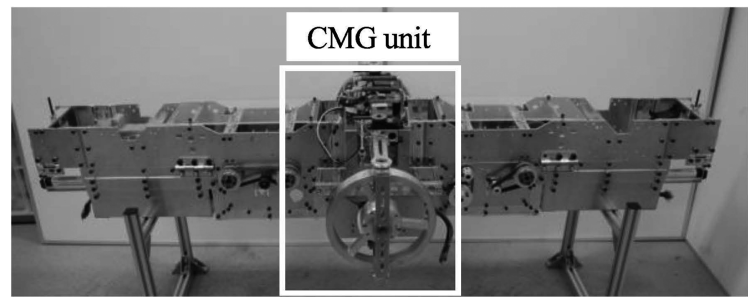

Fig. 3 Climber with CMG unit

$$
J \dot{\omega}+D \omega=K(i) i+T_{L}
$$

と表す。ただし，J, $D, K$ はそれぞれ慣性モーメント，粘性係 数, 推力定数を表すモータのパラメータである. $\omega$ は回転角速 度， $i$ は電流指令值を表し，モータに対する負荷トルクを $T_{L}$ と する。

式（1）で機体に取り付けた際のパラメータ誤差やクライマー 部分の特性を等価外乱 $d$ とすると式（1）は

$$
\begin{aligned}
J_{n} \dot{\omega}+D_{n} \omega= & K_{n} i+\left(J_{n}-J\right) \dot{\omega}+\left(D_{n}-D\right) \omega \\
& +\left\{K(i)-K_{n}\right\} i+T_{L} \\
= & K_{n} i+d
\end{aligned}
$$




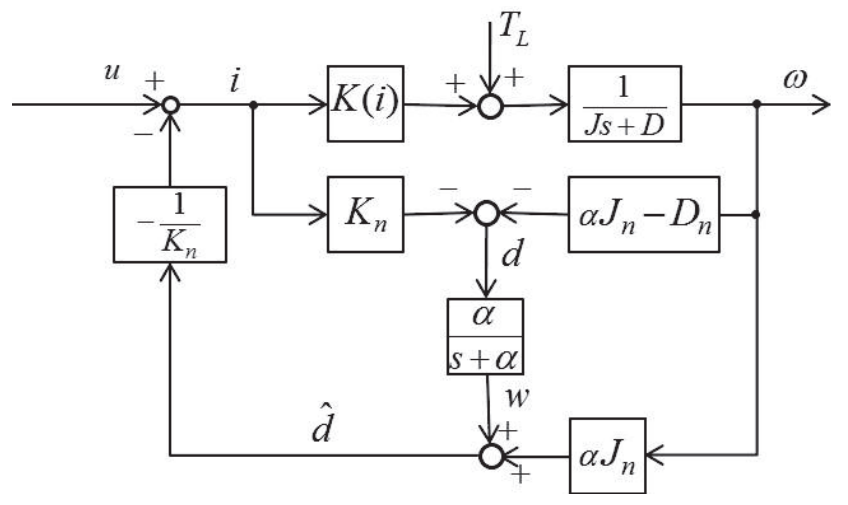

Fig. 4 Block diagram of disturbance observer

と表せる，ただし，添字の $n$ はノミナル值を表している.

式（2）に対して，極を $\alpha$ とする一次ローパスフィルタを通 して推定した等価外乱を $\hat{d}$ とすると

$$
\begin{aligned}
\hat{d} & =\frac{\alpha}{s+\alpha}\left(J_{n} \dot{\omega}+D_{n} \omega-K_{n} i\right) \\
& =\alpha J_{n} \omega+w \\
w & =-\frac{\alpha}{s+\alpha}\left(\alpha J_{n} \omega-D_{n} \omega+K_{n} i\right)
\end{aligned}
$$

となる。

Fig. 4 に示すように $\hat{d}$ を消去するように $u$ を外部入力として フィードバックを行うと

$$
i=u-\frac{1}{K_{n}} \hat{d}=u-\frac{1}{K_{n}}\left(\alpha J_{n} \omega+w\right)
$$

となる.このとき式 $(2)$ は $\hat{d}=d$ とすると，次式のようになる.

$$
J_{n} \dot{\omega}+D_{n} \omega=K_{n} u
$$

式（6）をモー夕 1, モータ 2 のモデルとし, モー夕 1 と 2 の 最適同期化速度制御系を構成する。このときモー夕 1,2 の変 数を下付数字の 1,2 で表すとこれらをまとめて

$\frac{d}{d t}\left[\begin{array}{l}\omega_{1} \\ \omega_{2}\end{array}\right]=\left[\begin{array}{cc}-\frac{D_{n}}{J_{n}} & 0 \\ 0 & -\frac{D_{n}}{J_{n}}\end{array}\right]\left[\begin{array}{l}\omega_{1} \\ \omega_{2}\end{array}\right]+\left[\begin{array}{cc}\frac{K_{n}}{J_{n}} & 0 \\ 0 & \frac{K_{n}}{J_{n}}\end{array}\right]\left[\begin{array}{l}u_{1} \\ u_{2}\end{array}\right]$

となり，これを離散化すると

$$
\left[\begin{array}{l}
\omega_{1}(k+1) \\
\omega_{2}(k+1)
\end{array}\right]=\left[\begin{array}{ll}
a & 0 \\
0 & a
\end{array}\right]\left[\begin{array}{l}
\omega_{1}(k) \\
\omega_{2}(k)
\end{array}\right]+\left[\begin{array}{ll}
b & 0 \\
0 & b
\end{array}\right]\left[\begin{array}{l}
u_{1}(k) \\
u_{2}(k)
\end{array}\right]
$$

となる。

式（8）に対して角速度目標值を $\omega_{r 1}(k)=\omega_{r 2}(k)=\omega_{r}(k)$, モータ 1 と 2 の速度誤差をそれぞれ $e_{1}(k), e_{2}(k)$, 両者の相対 速度差を $e_{12}(k)$ とすると

$$
\begin{gathered}
e_{1}(k)=\omega_{r}(k)-\omega_{1}(k) \\
e_{2}(k)=\omega_{r}(k)-\omega_{2}(k) \\
e_{12}(k)=\omega_{1}(k)-\omega_{2}(k)=e_{2}(k)-e_{1}(k)
\end{gathered}
$$

となる。

式（9）（11）の誤差を用いて次のエラーシステムを構成す る [5] [6]. ただし， $\Delta$ は一階差分值を表す。

$$
\begin{aligned}
{\left[\begin{array}{c}
e_{1}(k+1) \\
\Delta \omega_{1}(k+1) \\
e_{2}(k+1) \\
\Delta \omega_{2}(k+1)
\end{array}\right]=} & {\left[\begin{array}{cccc}
1 & -a & 0 & 0 \\
0 & a & 0 & 0 \\
0 & 0 & 1 & -a \\
0 & 0 & 0 & a
\end{array}\right]\left[\begin{array}{c}
e_{1}(k) \\
\Delta \omega_{1}(k) \\
e_{2}(k) \\
\Delta \omega_{2}(k)
\end{array}\right] } \\
& +\left[\begin{array}{cc}
-b & 0 \\
b & 0 \\
0 & -b \\
0 & b
\end{array}\right]\left[\begin{array}{c}
\Delta u_{1}(k) \\
\Delta u_{2}(k)
\end{array}\right]+\left[\begin{array}{l}
1 \\
0 \\
1 \\
0
\end{array}\right] \\
& \times \Delta \omega_{r}(k+1)
\end{aligned}
$$

あるいは

$$
\boldsymbol{X}(k+1)=\boldsymbol{\Phi} \boldsymbol{X}(k)+\boldsymbol{\Gamma} \Delta \boldsymbol{u}(k)+\boldsymbol{\gamma}_{r} \Delta \omega_{r}(k+1)
$$

式（12）に対して,

$$
\begin{aligned}
J & =\sum_{k=1}^{\infty}\left[e_{1}^{2}(k)+e_{2}^{2}(k)+\gamma e_{12}^{2}(k)+h_{1} \Delta u_{1}^{2}(k)+h_{2} \Delta u_{2}^{2}(k)\right] \\
& =\sum_{k=1}^{\infty}\left[\boldsymbol{X}^{T}(k) \boldsymbol{Q} \boldsymbol{X}(k)+\Delta \boldsymbol{u}^{T}(k) \boldsymbol{H} \Delta \boldsymbol{u}(k)\right]
\end{aligned}
$$

ただし，

$$
\boldsymbol{Q}=\left[\begin{array}{cccc}
1+\gamma & 0 & -\gamma & 0 \\
0 & 0 & 0 & 0 \\
-\gamma & 0 & 1+\gamma & 0 \\
0 & 0 & 0 & 0
\end{array}\right] \quad \boldsymbol{H}=\left[\begin{array}{cc}
h_{1} & 0 \\
0 & h_{2}
\end{array}\right]
$$

と評価関数を定義する. 式（13）で $\gamma$ は相対速度差の重みで あり，同期化速度制御を重視する場合にはこの值を大きく選定 する。

$\Delta \omega_{r}(k+1)=0$ として式（13）の評価関数を最小とするよ うな入力は,

$$
\begin{gathered}
\Delta \boldsymbol{u}(k)=\boldsymbol{F} \boldsymbol{X}(k) \\
\boldsymbol{F}=-\left[\boldsymbol{H}+\boldsymbol{\Gamma}^{T} \boldsymbol{P} \boldsymbol{\Gamma}\right]^{-1} \boldsymbol{\Gamma}^{T} \boldsymbol{P} \boldsymbol{\Phi} \\
\boldsymbol{P}=\boldsymbol{Q}+\boldsymbol{\Phi}^{T} \boldsymbol{P} \boldsymbol{\Phi}-\boldsymbol{\Phi}^{T} \boldsymbol{P} \boldsymbol{\Gamma}\left[\boldsymbol{H}+\boldsymbol{\Gamma}^{T} \boldsymbol{P} \boldsymbol{\Gamma}\right]^{-1} \boldsymbol{\Gamma}^{T} \boldsymbol{P} \boldsymbol{\Phi}
\end{gathered}
$$

となる.

式（14）を初期值を零として変形すると

$$
\begin{aligned}
& u_{1}(k)=f_{11} \sum_{i=1}^{k} e_{1}(i)+f_{12} \omega_{1}(k)+f_{13} \sum_{i=1}^{k} e_{2}(i)+f_{14} \omega_{2}(k) \\
& u_{2}(k)=f_{21} \sum_{i=1}^{k} e_{1}(i)+f_{22} \omega_{1}(k)+f_{23} \sum_{i=1}^{k} e_{2}(i)+f_{24} \omega_{2}(k)
\end{aligned}
$$

となり，構成した最適同期化速度制御系のブロック線図を Fig. 5 に示す. 


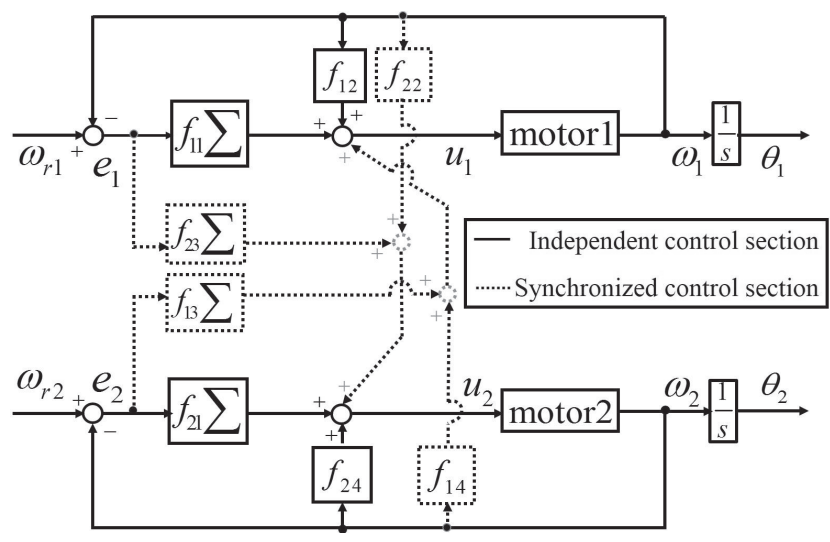

Fig. 5 Block diagram of constructed optimal synchronized velocity control system

\section{$3.2 \mathrm{CMG}$ ユニットの制御}

クライマーは上昇するため上昇方向の力が発生するが，今回 はモデルに考慮しないものとする.クライマーを中心としたテ ザー周りの CMG ユニットのモデルは次式のように表される [7].

$$
I \ddot{\phi}+C_{s} \dot{\phi}=T_{\text {out }}-2 H \dot{\theta} \cos \theta
$$

$I, C_{s}, H$ はそれぞれ $\mathrm{CMG}$ ユニットのテザー周りの慣性モー メント, 減衰係数, フライホイールの角運動量を表すパラメー 夕である. $\phi, \theta$ はテザー回りの回転角度とジンバルの回転角度 を表し，姿勢に対する外乱を $T_{\text {out }}$ とする.

ここでパラメータ誤差や外乱を等価外乱 $d$ とすることで式 （16）を

$$
I_{n} \ddot{\phi}+C_{s n} \dot{\phi}=-2 H_{n} \dot{\theta} \cos \theta+d
$$

と表す.

式 $(3) \sim(5)$ と同様にして等価外乱 $d$ を補償し， $u_{g}$ を外部 入力とすると式（17）は次式のように表される.

$$
I_{n} \ddot{\phi}+C_{s n} \dot{\phi}=-2 H_{n} u_{g}
$$

ただし,$u_{g}=\dot{\theta} \cos \theta$

サンプリング周期を $T$ として式（18）を離散化すると以下と なり,

$$
\begin{aligned}
\dot{\phi}(k+1) & =\left(1-\frac{C_{s n} T}{I_{n}}\right) \dot{\phi}(k)-\frac{2 H_{n} T}{I_{n}} u_{g}(k) \\
& =a_{g} \dot{\phi}(k)+b_{g} u_{g}(k)
\end{aligned}
$$

また台形近似を用いると

$$
\begin{aligned}
\phi(k+1) & =\phi(k)+\frac{T}{2}\{\dot{\phi}(k+1)+\dot{\phi}(k)\} \\
& =\phi(k)+\frac{T}{2}\left(1+a_{g}\right) \dot{\phi}(k)+\frac{T}{2} b_{g} u_{g}(k)
\end{aligned}
$$

となる。

ここでは最適サーボ系を構成する. 式（20）に対して, 角度 目標值を $\phi_{r}(k)$, 角度誤差を $e_{g}(k)$ として

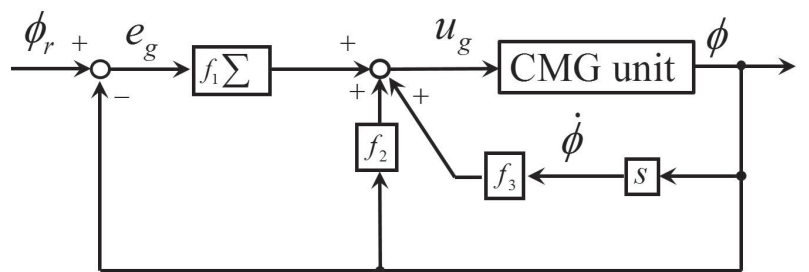

Fig. 6 Block diagram of constructed optimal CMG unit control system

$$
e_{g}(k)=\phi_{r}(k)-\phi(k)
$$

とすると以下のようなエラーシステムを構成する.

$$
\begin{aligned}
{\left[\begin{array}{c}
e_{g}(k+1) \\
\Delta \phi(k+1) \\
\Delta \dot{\phi}(k+1)
\end{array}\right]=} & {\left[\begin{array}{ccc}
1 & -1 & -T\left(1+a_{g}\right) / 2 \\
0 & 1 & T\left(1+a_{g}\right) / 2 \\
0 & 0 & a_{g}
\end{array}\right]\left[\begin{array}{c}
e_{g}(k) \\
\Delta \phi(k) \\
\Delta \dot{\phi}(k)
\end{array}\right] } \\
& +\left[\begin{array}{c}
-T b_{g} / 2 \\
T b_{g} / 2 \\
b_{g}
\end{array}\right] \Delta u_{g}+\left[\begin{array}{l}
1 \\
0 \\
0
\end{array}\right] \Delta \phi_{r}(k+1)
\end{aligned}
$$

あるいは

$$
\boldsymbol{X}_{g}(k+1)=\boldsymbol{\Phi}_{g} \boldsymbol{X}_{g}(k)+\gamma_{g} \Delta u_{g}(k)+\gamma_{g r} \Delta \phi_{r}(k+1)
$$

式（22）に対して,

$J=\sum_{k=1}^{\infty}\left[q_{1} e_{g}^{2}(k)+q_{2}\{\Delta \phi(k)\}^{2}+q_{3}\{\Delta \dot{\phi}(k)\}^{2}+h_{g}\left\{\Delta u_{g}\right\}^{2}\right]$

と評価関数を定義する.

$\Delta \phi_{r}(k+1)=0$ として式 $(23)$ の評価関数を最小とするよ うな入力は,

$$
\begin{gathered}
\Delta u_{g}(k)=\boldsymbol{f}_{g} \boldsymbol{X}_{g}(k) \\
\boldsymbol{f}=-\left[h_{g}+\boldsymbol{\gamma}_{g}^{T} \boldsymbol{P}_{g} \boldsymbol{\gamma}_{g}\right]^{-1} \boldsymbol{\gamma}_{g}^{T} \boldsymbol{P}_{g} \boldsymbol{\Phi}_{g} \\
\boldsymbol{P}_{g}=\boldsymbol{Q}_{g}+\boldsymbol{\Phi}_{g}^{T} \boldsymbol{P}_{g} \boldsymbol{\Phi}_{g}-\boldsymbol{\Phi}_{g}^{T} \boldsymbol{P}_{g} \boldsymbol{\gamma}_{g}\left[h_{g}+\boldsymbol{\gamma}_{g}^{T} \boldsymbol{P}_{g} \boldsymbol{\gamma}_{g}\right]^{-1} \boldsymbol{\gamma}_{g}^{T} \boldsymbol{P}_{g} \boldsymbol{\Phi}_{g} \\
\boldsymbol{Q}_{g}=\left[\begin{array}{ccc}
q_{1} & 0 & 0 \\
0 & q_{2} & 0 \\
0 & 0 & q_{3}
\end{array}\right]
\end{gathered}
$$

となる。

式（24）を初期值を零として変形すると

$$
u_{g}(k)=f_{1} \sum_{i=1}^{k} e_{g}(i)+f_{2} \phi(k)+f_{3} \dot{\phi}(k)
$$

となり，構成した最適サーボ系のブロック線図を Fig. 6 に示す.

\section{4. 実験による検証}

\section{1 クライマー本体の性能評価実験}

製作したロープ型クライマーの昇降実験を行った。実験は 


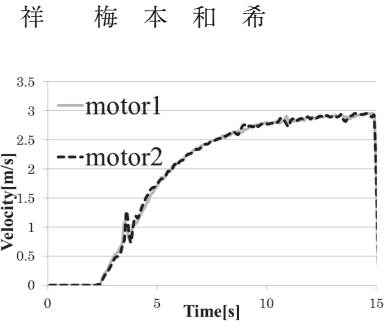

(a) Synchronized control

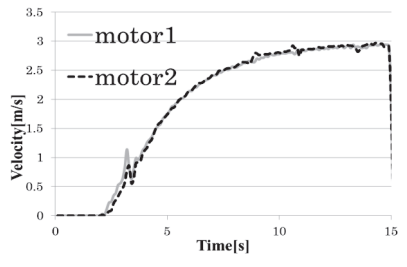

(b) Independent control

Fig. 8 Experimental results to load change (velocity)

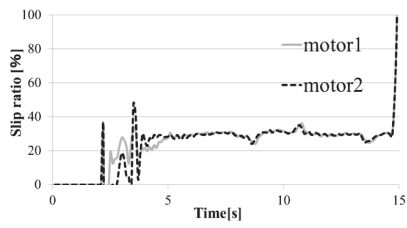

(a) Synchronized control

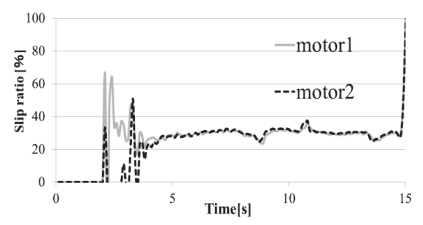

(b) Independent control

Fig. 7 Outdoor test site of Kanagawa University

Fig. 7 に示す高度 $25[\mathrm{~m}]$ の神奈川大学の屋外実験場で $20[\mathrm{~m}]$ の昇降実験を行った、ロープテザーは高張力, 耐疲労性, 寸法 安定性，耐熱性などの特性をもつ帝人製パラアラミド繊維テク ノーラを外層, ダイニーマとポリプロプレンの混紡を内層とし た直径 $11[\mathrm{~mm}]$ の 2 重構造（重量 $85[\mathrm{~g} / \mathrm{m}]$ ）のものを用いてお り，ロープテザーが緩まないように $500 \sim 1,000[\mathrm{~N}]$ 程度の十分 な張力を掛けている.

ノミナル值は $J_{n}=1.0, D_{n}=1.0, K_{n}=10.0$, 評価関数 の重みは, $\gamma=50, h_{1}=h_{2}=40$ としている. マイコンは STBee を用い, サンプリング周期は $100[\mathrm{~ms}]$ で行った. 回転 速度の測定にはエンコーダを使用し, $3[\mathrm{~m} / \mathrm{s}]$ のステップ目標值 を与えている。

Fig. 8〜10 に二つのローラのうち片方のローラの押し付けを 緩めて負荷を変化させ, 最適同期化速度制御を行った場合のモー 夕の回転速度が走行時の負荷特性の変化に対応できるかどうか を検証した実験結果を示す. Fig. 8 にモータの回転速度, Fig. 9 にスリップ率，Fig. 10 に累積速度誤差を示す.

これらより，2 個のローラは外乱オブザーバを用いて等価外 乱を除去したモデルを用いて制御され，お互いに同期しながら 目標速度に近づいていることが分かる. また，同期時のほうが 滑りやすい始動時においても速度差が小さくスリップ率の差も 小さくなっていることや, 二つのモータの累積速度誤差が同期 化速度制御を行っているときのほうが少ないことも分かる.

\section{2 宇宙エレベーターチャレンジでの長距離実験}

第 6 回宇宙エレベーターチャレンジは 2014 年 8 月 6 9 日 に, 静岡県富士宮市の大沢扇状地で実施された. チャレンジで はバルーンでテザーを高度 $1,200[\mathrm{~m}]$ まで上昇させて行い, 大 学の実験施設等では行うことができない長距離高高度の実験が 可能となる. 今回は, 上昇目標距離を $1,200[\mathrm{~m}]$ とし $4[\mathrm{~m} / \mathrm{s}]$ の 速度目標值で実験を行った. Fig. 11 にこの結果を示す.チャ レンジ中にはかなりの強風によりロープは激しく振動し, 地心 鉛直方向からも大きくずれていたが, 結果は非常に安定して走 行しており，長距離でも 2 個のモータがお互いに同期しながら 目標速度に近づいていることが分かる.

Fig. 9 Experimental results to load change (slip ratio)

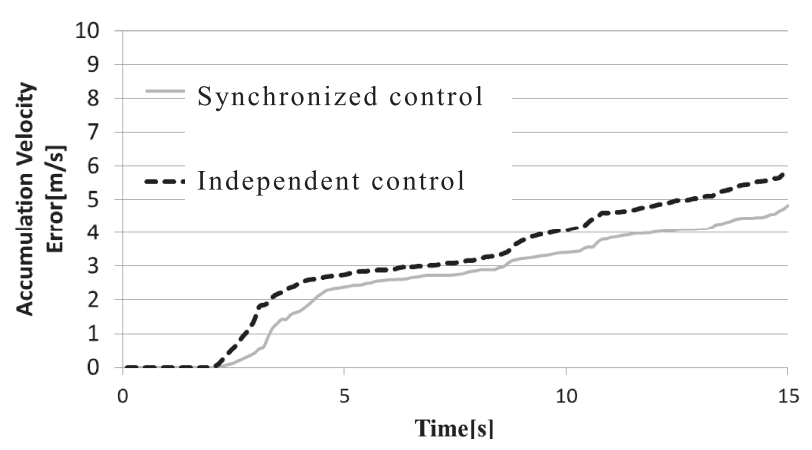

Fig. 10 Experimental results to load change (Accumulation velocity error)

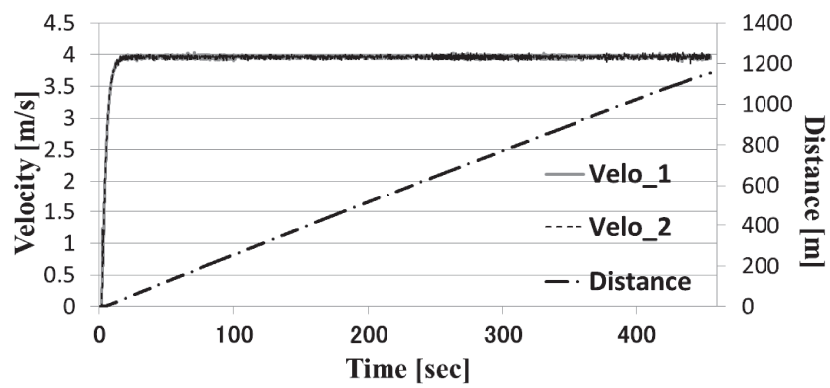

Fig. 11 Results of Space Elevator Challenge 2014

\section{3 CMG ユニットを搭載した性能評価}

次に CMG ユニットをロープ型クライマーに搭載したときのシ ミュレーションおよび実験結果を示す.ノミナル值は $I_{n}=1.0$, $C_{s n}=1.0, H_{n}=1.0$, 評価関数の重みは, $q_{1}=1, q_{2}=5$, $q_{3}=5, h=100$ としている. マイコンは Arduuino Uno R3 を用い, サンプリング周期は $100[\mathrm{~ms}]$ とした. 今回用いた CMG ユニットはジンバルの角度 $\theta$ は $\pm 90^{\circ}$ に達すると必要方向にト ルクが発生しない飽和特異点が存在する。 そのため有効角度を $\pm 45^{\circ}$ にしている.

まず最初に Fig. 12 に示す卓上実験装置のポール上に CMG ユニットを設置し, 摩擦が少ない状態で姿勢制御実験を行った. 


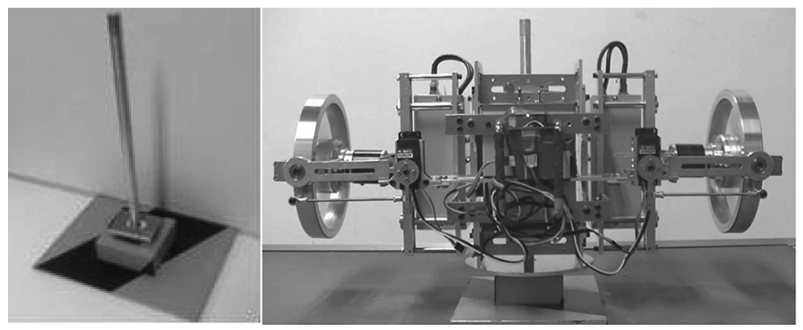

Fig. 12 Table experimental equipment

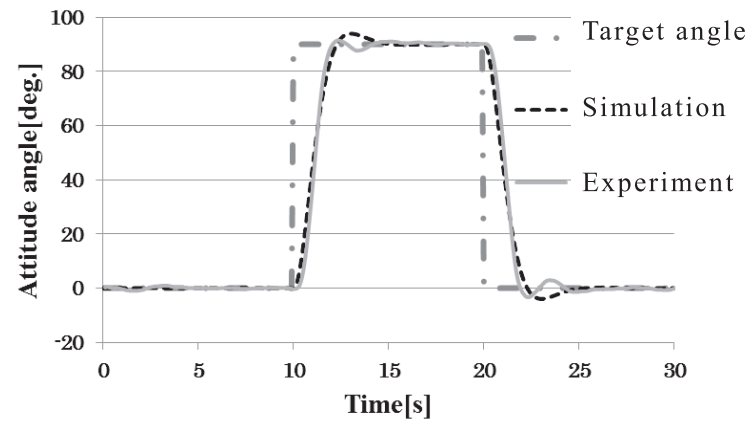

Fig. 13 Table experimental results

角度の測定には 9 軸ジャイロセンサを使用した. シミュレーショ ンおよび実験結果を Fig. 13 に示す。ポール周りの姿勢角度目 標值を 0-90-0としている. シミュレーション結果と実験結果 を比べるとほぼ一致しており，良好な角度応答が得られている のが分かる．今回用いた CMG ユニットのパラメータは実際の パラメータとは必ずしも一致していないが，外乱オブザーバの 効果によりこのような結果が得られていると考えられる.

次に Fig. 12 に示した CMG ユニットを搭載した実験用クラ イマーのロープテザー周りの姿勢制御について検討するために, 昇降中に姿勢制御を行う実験を行った。実験場所はFig. 7 と同 じである．実験の様子を Fig. 14 に示す．実験方法は $25[\mathrm{~m}]$ 昇 降中に 0-90- $0^{\circ}$ と 0-60-120-180の 2 種類のテザー周りの機 体の姿勢角度制御を行った. シミュレーションおよび実験結果 をFig. 15 に示す.どちらも目標姿勢角に良好に追従しており， シミュレーション結果と実験結果はほぼ一致し，屋外実験にお ける卓上実験より大きな外乱にも対応できていることが分かる。 なお，クライマーがジャイロ効果によりロープテザー周りを回 転するときは，ロープテザーとローラの間に滑りが生じている ことは確認している.

\section{5. おわりに}

本論文において，外乱オブザーバを用いて等価外乱を除去し たノミナルモデルを用いて，ロープ型クライマーの最適同期化 速度制御系を構築し，スリップ率や二つのモータ間の累積速度 誤差の低減を実現できた。 また，宇宙エレベーターチャレンジで は，今まで行えていなかった長距離における最適同期化速度制 御や外乱オブザーバの有効性を示すことができ，ロープ型では 世界最高高度記録となる $1,150[\mathrm{~m}]$ の昇降をすることができた。

$\mathrm{CMG}$ ユニットを搭載した場合にも機体の目標姿勢角への最 適サーボ系のよる角度制御は成功しており，測定した值もほぼ

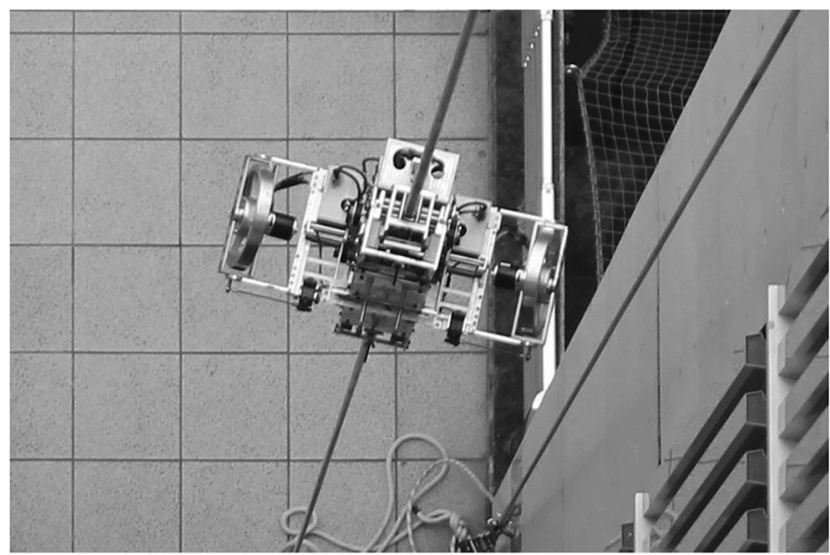

Fig. 14 Lift experiment at the outdoor test site

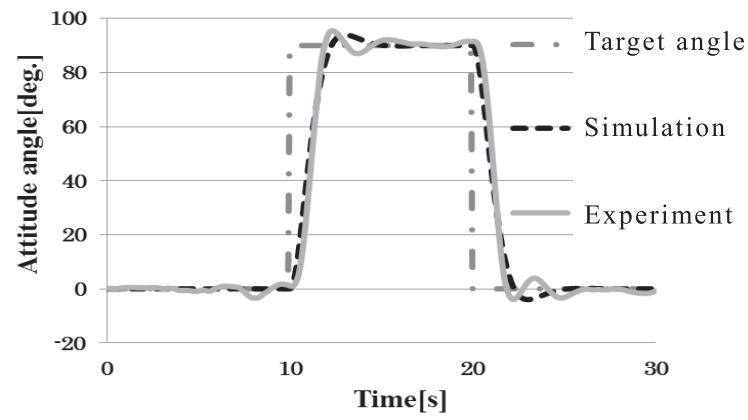

(a) $0-90-0^{\circ}$

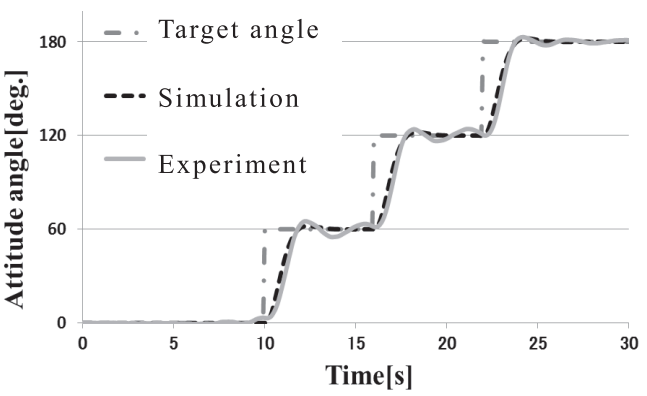

(b) $0-60-120-180^{\circ}$

Fig. 15 Outdoor experimental results

シミュレーションどおりの結果となっているため, CMG ユニッ トと外乱オブザーバの有効性を示すことができた.

本ユニットは 1 自由度系の $\mathrm{CMG}$ を用いており，1 自由度系 の $\mathrm{CMG}$ は飽和特異点の回避が困難とされている. 本ユニット は長距離走行，長時間での稼働を想定しているため，飽和特異 点の影響を避けて通ることができず，今後この回避についての 検討が課題である.

なお，本研究にご協力いただいた神奈川大学大学院大場雄斗 君，神奈川大学松野千加士主任技術員ならびに守屋元道技術員 に深謝致します.

\section{参 考 文 献}

[1] B.C. Edward and P. Ragan: Leaving the Planet by Space Elevator, Lulu. com, 2006

[2 ] 大林組プロジェクトチーム：“宇宙エレベーター」建設構想”, 季刊 
大林, no.53, pp.30-59, 2012.

[3] 大西公平：“外乱オブザーバによるロバスト・モーションコントロー ル”, 日本ロボット学会誌, vol.11, no.4, pp.486-493, 1993.

[4] K. Ohnishi, M Shibata and T. Murakami: "Motion control for advanced mechatronics," IEEE/ASME Trans. Mechatronics, vol.1, no.1, pp.56-67, 1996.
[ 5 ] 江上正, 依田一宏：“メカトロサーボ系の最適同期化経路制御”, 計測 自動制御学会論文集, vol.34, no.9, pp.1178-1183, 1998.

[ 6 ] 土谷武士, 江上正: 新版現代制御工学. pp.195-227, 産業図書, 1991.

[ 7 ] 星尾光紀, 梅村克哉, 神吉博： “コントロールジャイロモーメントを 用いた減摇装置”，三菱重工技法，vol.31, no.3, pp.213-216, 1994.

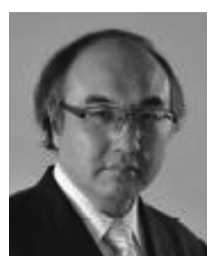

\section{江上 正 (Tadashi Egami)}

1987 年北海道大学大学院工学研究科電気工学専攻 博士課程修了. 工学博士. 1987 年神奈川大学工学部 機械工学科専任講師. 1990 年同助教授, 1997 年同 教授，現在に至る.メカニカルシステムのモーショ ンコントロールに興味を持ち，車椅子，ロボット， 宇宙エレベーター実験用クライマーなどの開発と制 御に関する研究を行っている. 計測自動制御学会, 電気学会, システ 厶制御情報学会, 日本機械学会, IEEE の会員. 宇宙エレベーター協 会フェロー。

（日本ロボット学会正会員）

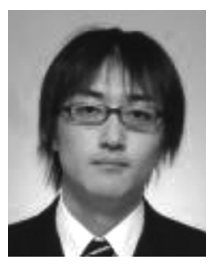

梅本和希 (Kazuki Umemoto)

2014 年京都大学大学院工学研究科機械理工学専攻 博士後期課程修了. 博士 (工学). 同年神奈川大学 工学部機械工学科特別助教となり現在に至る. 非線 形制御, ロバス卜制御の研究を行っている. システ 厶制御情報学会, 計測自動制御学会, IEEE の会員.

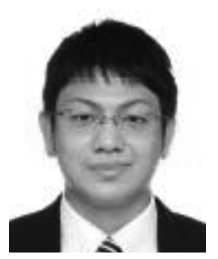

長島 祥 (Akira Nagashima)

2015 年神奈川大学大学院工学研究科機械工学専攻 博士前期課程修了. 修士 (工学). 2015 年より TDI プロダクトソリューション株式会社勤務, 現在に至 る. 在学中は宇宙エレベーター実験用クライマーの 開発と制御に関する研究を行った。 